\title{
Morphology and Corrosion Behavior of Zn-Ni Layers Electrodeposited on Low Alloy Carbon Steel Substrate
}

\author{
Fateh Chouia ${ }^{1,2}$, Abdelouahad Chala ${ }^{1,2}$, Abdelghani Lakel $^{2,3^{*}}$, Toufik Sahraoui ${ }^{4}$ \\ ${ }^{1}$ Laboratory of Thin Film Physics and Applications, University of Biskra, BP 145 RP, Biskra 07000, Algeria \\ ${ }^{2}$ Material Sciences Department, Faculty of Science, University of Biskra, Biskra 07000, Algeria \\ ${ }^{3}$ Laboratory of Metallic and Semiconducting Materials, University of Biskra, BP 145 RP, Biskra 07000, Algeria \\ ${ }^{4}$ Department of Mechanical Engineering, University of Biskra, BP 145 RP, Biskra 07000, Algeria
}

Corresponding Author Email: a.lakel@univ-biskra.dz

https://doi.org/10.18280/acsm.450305

Received: 28 December 2020

Accepted: 16 March 2021

\section{Keywords:}

corrosion, Zn-Ni layers, morphology, electroplating, low alloy steel

\begin{abstract}
The aim of this work is to improve the microstructure, the morphology, the mechanical and the corrosion behavior of $\mathrm{Zn}-\mathrm{Ni}$ layers electrodeposited on low alloy carbon steel. Some factors such as the nickel concentration in the electrolyte, the electrolyte temperature and the current density are studied and optimized. The efficiency of the layers to protect the low alloy carbon steel against corrosion in $\mathrm{HCl}$ solution is also studied in this work. The electrodeposited $\mathrm{Zn}-\mathrm{Ni}$ layers morphologies and microstructure were investigated by Scanning Electronic Microscopy (SEM) and X-ray diffraction (XRD) respectively. The best deposits of $\mathrm{Zn}-\mathrm{Ni}$ layers are obtained with $50 \%-\mathrm{Ni}$ in the electrolyte bath at a temperature of $40^{\circ} \mathrm{C}$ and a current density of $\mathrm{j}=3 \mathrm{~A} \mathrm{dm}^{-2}$. The XRD spectrum showed the coexistence of two phases: $\delta$-phase (Ni3Zn22) and $\gamma$-phase (Ni5Zn21), and a pyramidal morphology is detected by SEM. The lost mass method results showed that the corrosion rate tacked a steady state between 10 and $50 \%$ of $\mathrm{Ni}$, and it increased with the increase of $\mathrm{Ni}$ amount in the electrolyte bath.
\end{abstract}

\section{INTRODUCTION}

Corrosion causes significant deterioration of the overall properties and durability of metallic materials and is a major threat to structural safety, safety of life, environmental health and economic growth [1]. As metals come into contact with various environments, such as air, water, chemical compounds or pollutants, they tend to decay due to the interaction of metal with the environment [2].

In many sectors, low alloy carbon steel is most often used as a construction material due to its superior mechanical properties and low-cost maintenance. It is used in large tonnages for marine uses, chemical manufacturing processes of oil extraction and refining, machinery for construction and metal processing. Acid solutions are widely used in industry, such as chemical washing, descaling, pickling and oil-well acidification, petrochemical systems, boilers, containers, heat exchangers, reservoirs, etc., contributing to corrosive assaults $[3,4]$.

The possibilities provided by the electrodeposition of alloys, primarily in the automotive industry, have shown considerable interest in recent years. The mechanical and chemical properties of metals are typically strengthened by alloying [5].

Increased automotive warranty period and the criteria for metallic coatings with greater corrosion resistance than pure zinc led to the manufacture of electrodeposits based on zinc alloys of metals from eight classes of metals ( $\mathrm{Zn}-\mathrm{Ni}, \mathrm{Zn}-\mathrm{Co}$, and $\mathrm{Zn}-\mathrm{Fe})$ [6, 7]. The electrodeposition of zinc-nickel coatings has drawn significant interest because, relative to bare zinc and other zinc alloy coatings, these alloys exhibit higher corrosion resistance, improved mechanical properties and better thermal stability $[8,9]$. While the first electrolytes were sulphate-based, in recent years chloride baths have been favored due to their higher conductivity [10].

The resistance of the $\mathrm{Zn}-\mathrm{Ni}$ alloy to corrosion is basically dependent on the Ni percentage. In addition, the presence of various additives in the electrodeposition bath increased surface homogeneity, leading to improved corrosion resistance, even for a low $\mathrm{Ni}$ content alloy [11-13]. Zn-Ni alloys with a 12-14 wt.\% Ni content have the highest corrosion properties and can be many times stronger than a pure zinc coating of the same thickness [9]. Although the $\mathrm{Zn}-\mathrm{Ni}$ deposition method from electrolytes of various compositions has been intensively studied in the last two decades, the impact of electrolyte composition and plating conditions on the alloy's composition, microstructure and properties remains unclear [8].

The aim of the present investigation is to establish a correlation between the morphology and the different deposition parameters such as electrolyte concentration, current density and bath temperature; on the influence of these later on the corrosive behavior of electrodeposited $\mathrm{Zn}-\mathrm{Ni}$ layers.

\section{MATERIALS AND METHODS}

The substrate used in this study is an industrial low alloy carbon steel $(0.19 \mathrm{wt} . \% \mathrm{C})$. The chemical composition of the present substrate is given in Table 1. Abrasive paper was used to remove contamination from the surface of the substrates which were degreased by anodic and cathodic electrolysis for 
2 minutes in $35 \mathrm{~g} / 1 \mathrm{NaOH}$ solution and $25 \mathrm{~g} / 1 \mathrm{Na}_{2} \mathrm{CO}_{3}$ at 6 $\mathrm{Adm}^{-2}$ [14]. The low alloy carbon steel plates were then neutralized in $10 \% \mathrm{HCl}$ solution for 5 minutes to activate the surface and rinsed in distilled water. In order to electrodeposit the $\mathrm{Zn}-\mathrm{Ni}$ coating on the cleaned substrates, five electrolyte baths were prepared by varying the nickel percentage compositions $(10,25,50,75$ and $90 \%)$, which are named $10 \mathrm{Ni}$, $25 \mathrm{Ni}, 50 \mathrm{Ni}, 75 \mathrm{Ni}$ and $90 \mathrm{Ni}$ respectively. Table 2 represents the different baths used for the electrodeposition of $\mathrm{Zn}-\mathrm{Ni}$ films and the preparation conditions. The chloride bath is used to investigate the mechanism of zinc-nickel deposition. $\mathrm{NH}_{4} \mathrm{Cl}$ and $\mathrm{KCl}$ were added to increase the conductivity and ionic strength of the electrolyte. Boric acid is used to maintain the $\mathrm{pH}$ of the bath [15]. Also, boric acid acts as a buffer to maintain $\mathrm{pH}$ of the electrolyte bath [16].

For the phase identification, X-rays measurements (by using an X'Pert PRO (PANalytical)) were carried out with the use of a $\mathrm{Cu} \mathrm{K} \alpha$ wavelength $(\lambda=1.5418 \AA)$ under $40 \mathrm{kV}$ and $30 \mathrm{~mA}$. The observed morphologies of the prepared samples were viewed using scanning electron microscopy, SEM (JEOL JSM-9390LV). For the mechanical properties measurements, a Vickers microhardness indenter (Indentec ZHV) was used to indent the prepared $\mathrm{Zn}-\mathrm{Ni}$ alloys with a diamond tip, with an applied load of $200 \mathrm{~g}$ for $15 \mathrm{~s}$. The corrosion tests were carried out using the lost mass method. The weight of samples was measured by using a sensitive microbalance before immersion in a solution of $\mathrm{HCl}(0.6 \mathrm{M})$ for a period of 20 days at $25^{\circ} \mathrm{C}$. After that, the samples are removed from the solution, rinsed with distilled water and then dried.

The corrosion rate (W) in the present investigation was calculated using the following expression [17]:

$$
\mathrm{W}=\left(\mathrm{m}_{1}-\mathrm{m}_{2}\right) / \mathrm{At}
$$

where, $\mathrm{m}_{1}$ and $\mathrm{m}_{2}$ are the weight losses (mg)before and after immersion in the test solutions, $\mathrm{A}$ is the area of the specimens $\left(\mathrm{cm}^{2}\right)$ and $\mathrm{t}$ is the exposure time (h).

Table 1. Chemical composition of industrial low carbon steel (0.19 wt.\% C)

\begin{tabular}{cccccccccc}
\hline Element & $\mathbf{C}$ & $\mathbf{S i}$ & $\mathbf{M n}$ & $\mathbf{P}$ & $\mathbf{S}$ & $\mathbf{A l}$ & $\mathbf{N}$ & $\mathbf{N b}$ & $\mathbf{T i}$ \\
\hline wt.\% & 0.19 & 0.25 & 0.40 & 0.025 & 0.015 & 0.02 & 0.009 & 0.050 & 0.03 \\
\hline
\end{tabular}

Table 2. Bath composition and deposition conditions

\begin{tabular}{cccc}
\hline & Concentration (g/l) & Concentration (mol/l) & Conditions \\
\hline $\mathrm{NiCl}_{2}, 6 \mathrm{H}_{2} \mathrm{O}$ & $14-28$ & $0.06-0.54$ & Anode: pure $\mathrm{Zn}$ \\
$\mathrm{ZnCl}_{2}$ & $73-8$ & $0.54-0.06$ & $\mathrm{pH}=4,44$ \\
$\mathrm{NH}_{4} \mathrm{Cl}$ & 119,748 & 2.24 & Operation time: 60 minutes \\
$\mathrm{H}_{3} \mathrm{BO}_{3}$ & 30,905 & 0.5 & Temperature $: 30,40,70$ and $90^{\circ} \mathrm{C}$ \\
$\mathrm{KCl}$ & 120,027 & 1.61 & Current density: $1.5,2,2.5,3$ and $3.5 \mathrm{~A} \mathrm{dm}^{-2}$ \\
\hline
\end{tabular}

\section{RESULTS AND DISCUSSION}

\subsection{X- ray diffraction}

According to the $\mathrm{Zn}-\mathrm{Ni}$ phase diagram and some studies [8, 18], electrodeposited $\mathrm{Zn}-\mathrm{Ni}$ alloys have four main phases: the alpha phase, a solid zinc solution in nickel with an equilibrium solubility of approximately $30 \% \mathrm{Zn}$; the $\gamma$ phase, an intermediate phase with a composition of $\mathrm{Ni}_{5} \mathrm{Zn}_{21}$; the $\delta$ phase, an intermediate phase with a composition of $\mathrm{Ni}_{3} \mathrm{Zn}_{22}$; and the alpha phase, a solid nickel solution in zinc with a composition of less than $1 \%$ nickel.

Figure 1 displays the X-ray diffraction curves of $\mathrm{Zn}-\mathrm{Ni}$ coatings in the electrolyte bath with various proportions of $\mathrm{Ni}$ components, 10 (Figure 1a), 25 (Figure 1b), 50 (Figure 1c), 75 (Figure 1d) and 90 percent (Figure 1d) respectively. The patterns of the XRD in the Figure1 (b-e) present two highintensity peaks (located at $2 \theta=42.87$ and $62.3^{\circ}$ ) coexisting with several mild nickel electrolyte peaks in the case of 25,50 , 75 and $90 \%$ respectively, while a single higher-intensity peak $\left(2 \theta=42.87^{\circ}\right)$ was found in the case of $10 \%$ Ni (Figure 1a). Alloy showed a $\gamma$ phase $\left(\mathrm{Ni}_{5} \mathrm{Zn}_{21}\right)$ or a combination of two phases $\left(\mathrm{Ni}_{3} \mathrm{Zn}_{22}\right)$ and $\gamma$. These findings are in accordance with the studies in the literature [19]. The existence of various phases in the deposits depends on the relative amount of $\mathrm{Ni}$ and $\mathrm{Zn}$. The passive layer is formed by the dissolution of zinc during this phase. In comparison, phase $\gamma\left(\mathrm{Ni}_{5} \mathrm{Zn}_{21}\right)$ does not exhibit the same behavior that could be associated with its higher stability. It has been stated in the literature [8, 20-22] that alloys with a nickel content of $12 \%$ consist solely of intermetallic $(\delta$-phase $) \mathrm{Ni}_{3} \mathrm{Zn}_{22}$. The improvement in the nickel content by up to 19 at. $\%$ contributes to the development of an intermetallic ( $\gamma$-phase) $\mathrm{Ni}_{5} \mathrm{Zn}_{21}$ with a cell parameter lower than that of the pure $\gamma$-phase $[8,22]$. It may therefore be inferred that the plating bath type and the nickel content of the alloys have a profound effect on the alloy phase structure.
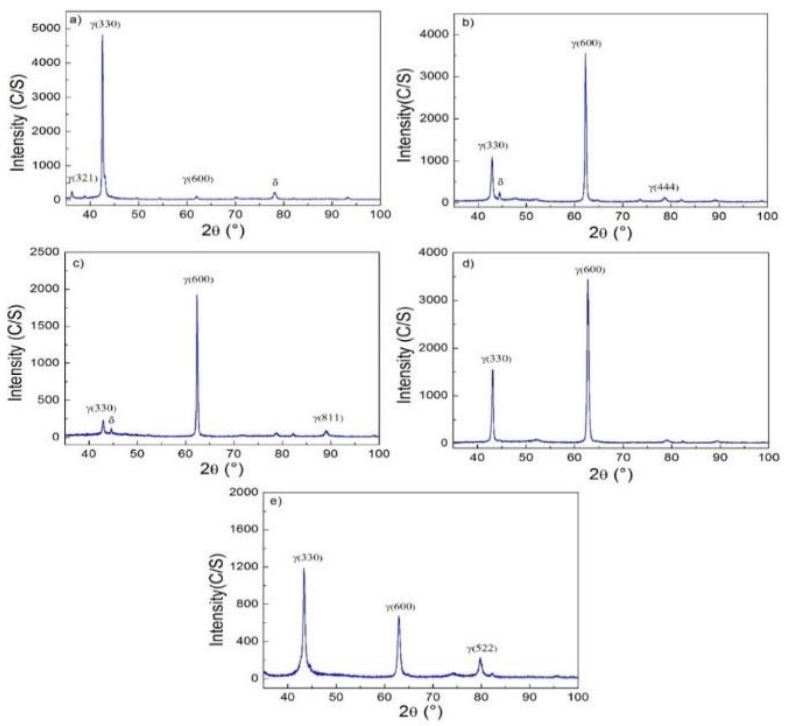

Figure 1. X-ray diffractogram for the $\mathrm{Zn}-\mathrm{Ni}$ coating with bath containing: a) $10 \mathrm{Ni}$, b) $25 \mathrm{Ni}$, c) $50 \mathrm{Ni}$, d) $75 \mathrm{Ni}$ and e) $90 \mathrm{Ni}$, with bath temperature $30^{\circ} \mathrm{C}$, current density $\mathrm{j}=3 \mathrm{~A} \mathrm{dm}^{-2}$ and $\mathrm{pH}=4.44$ 
These findings are in line with other experiments that show that increasing the nickel ions in the bath raises the nickel content in the deposition. It is hypothesized that the linear interaction found in the low range of $\mathrm{NiCl}_{2}$ is consistent with the assumption that the effect controls nickel ion reduction. With increasing $\mathrm{NiCl}_{2}$ concentrations, the deposit includes the phase $\gamma$. Similar effects of fluctuations in the concentration of in the bath at the lower range result in higher relative changes in the chemical composition and the phase presence in the closer control of bath chemistry [23].

\subsection{Morphology of deposits}

\subsubsection{Effect of current density}

The Figure 2 presents the SEM micrograph of Zn-Ni layers electrodeposited on low alloy carbon steel with a nickel concentration of $50 \%$ in electrolyte bath and at a temperature of $30^{\circ} \mathrm{C}$. The current density is varied and take the values of $\mathrm{j}=1.5$ (Figure 2a), 2 (Figure 2b), 2.5 (Figure 2c), 3 (Figure 2d) and $3.5 \mathrm{~A}^{-\mathrm{dm}^{-2}}$ (Figure 2e). The electrodeposited time was fixed at $60 \mathrm{~min}$ [22]. It is clear that all SEM micrographics indicate that in the deposition system, the current density plays a very important role. The granular morphology of the coatings relies on the deposited layers' chemical composition.

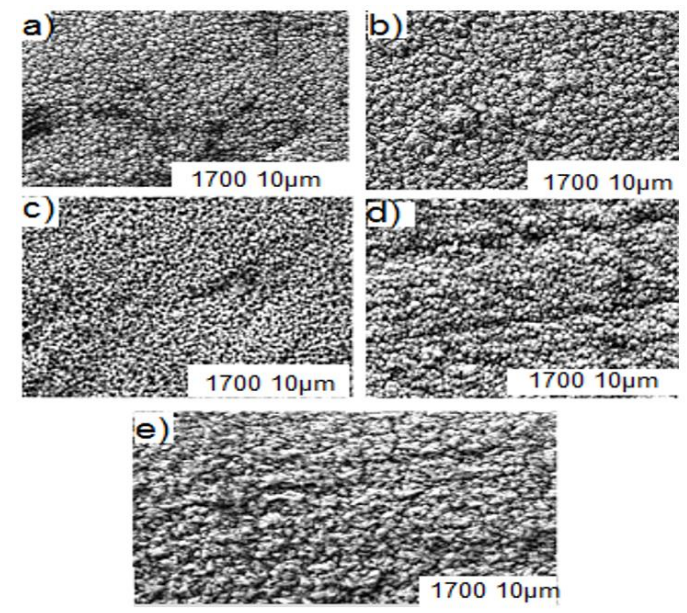

Figure 2. SEM micrographs $\mathrm{Zn}-\mathrm{Ni}$ deposits prepared at different current density: a) $1.5 \mathrm{~A} \mathrm{dm}^{-2}$, b) $2 \mathrm{~A} \mathrm{dm}^{-2}$, c) $2.5 \mathrm{~A}$ $\mathrm{dm}^{-2}$, d) $\mathrm{j}=3 \mathrm{~A} \mathrm{dm}^{-2}$ and e) $3.5 \mathrm{~A} \mathrm{dm}^{-2}$, with a Nickel concentration of $50 \%$ in electrolyte bath and at a temperature of $30^{\circ} \mathrm{C}$ and $\mathrm{pH}=4.44$

A large nodular grain agglomerate with several cracks is seen in Figure 2a, which may be due to the presence in the deposited substrate of a high nickel material. The improvement in current density to $2 \mathrm{~A} \cdot \mathrm{dm}^{-2}$ leads to a compact deposit layer for most uniform grains. In the deposits, some voids were found, which could be caused by the decrease in the proportion of nickel deposited [5]. No change in deposit morphology at current density from 3 to $3.5 \mathrm{~A} . \mathrm{dm}^{-2}$ (Figure 2 (d-e)) with the exception of reducing voids. At low current density, the nickel content of the alloy is comparatively high, resulting from the more noble aspect of nickel [24]. This can be explained by the fact that because the deposition rate is sluggish at low current density, at the beginning of the electrolysis, the sheet deposits as a large number of tiny particles on almost all the surface of the cathode act as a nucleation for further deposition at preferential locations [25]. Moreover, at high current density side increased \%Ni because the preferentially deposited less noble metal is more depleted in the cathode diffusion layer than is the more noble metal [14, 26]. All the gas formed on the surface of the cathode during the electrolysis process cannot escape, rather it is captured by a rapidly rising deposit. In addition, these gasses may develop as nucleation and growth processes, such as embedded alloys, and eventually, when escaped on their own accord, they may generate porosity [25].

\subsubsection{Effect of the bath temperature}

The $\mathrm{Zn}-\mathrm{Ni}$ deposit morphologies are presented in Figure 3(a-d) at different temperature bath: $\mathrm{T}=30$ (Figure $3 \mathrm{a}$ ), 40 (Figure 3b), 70 (Figure $3 \mathrm{c}$ ) and $90^{\circ} \mathrm{C}$ (Figure 3c). It is obvious that, the Figure $3 \mathrm{a}\left(\right.$ at $\mathrm{T}=30^{\circ} \mathrm{C}$ ) shows some cracks and voids in the resulting deposit morphology. The deposit prepared at a temperature of $40^{\circ} \mathrm{C}$ gives us a uniform and compact pyramidal structure, consisting of several large grain size films. The presence of a pyramidal morphology was due to the greater quantity of zinc in the layer (with an amount of $13 \%$ Nickel in the deposit) $[21,22]$. Increasing the temperature from 70 to $90^{\circ} \mathrm{C}$ activates the electrodepositing Nickel, which consequently creates a significant amount of nickel in the layers, so the deposit becomes irregular and non-uniform, while some fine cracks occur on the coating surface. This was similar to other works noted elsewhere. [5, 22-28]. The cause behind this behavior may be the higher development of $\mathrm{Ni}$. However, $\mathrm{Ni}$ is very temperature-sensitive with greater activation energy, according to Arrhenius law [22]. The presence of cracks in the coating was due to hydrogen by Abd El Rehim et al. [29]. In this research, it was noted that the evolution of hydrogen corresponding to the partial current density of hydrogen increases with the rise in deposition temperature and reaches a limit of $70^{\circ} \mathrm{C}$. Through the reduction of hydrogen, some hydrogen atoms absorb on the surface of the coating and disperse within the coatings, so the crystal lattice of the coating could be stressed by hydrogen atoms stuck in the coating, and a strong residual stress occurs. The evolution of hydrogen gets so extreme as the temperature rises to $70^{\circ} \mathrm{C}$ that more hydrogen atoms can be stuck in the coating. Cracks could be created when residual stress exceeds a certain level [22].

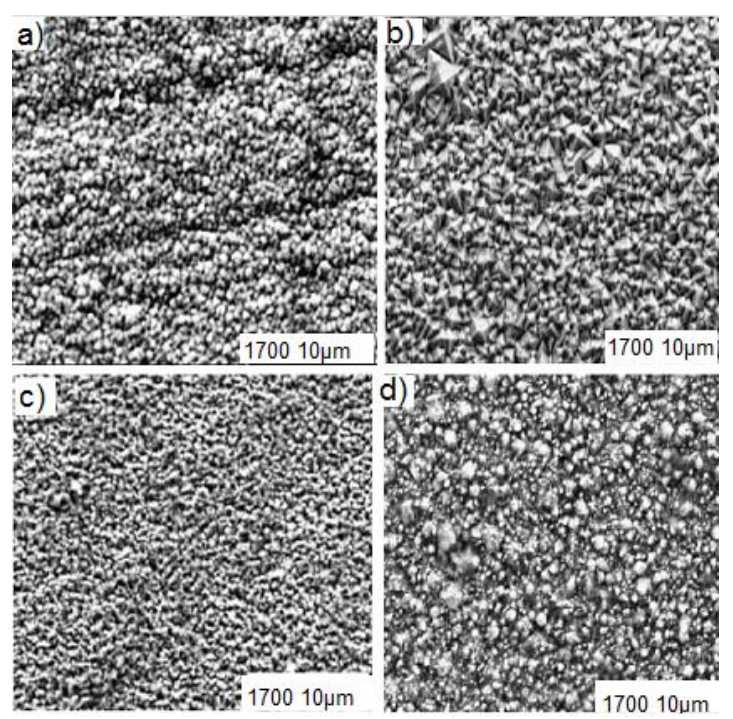

Figure 3. SEM micrographs $\mathrm{Zn}-\mathrm{Ni}$ deposits prepared at different bath temperature: a) $30^{\circ} \mathrm{C}$, b) $40^{\circ} \mathrm{C}$, c) $70^{\circ} \mathrm{C}$ and e) $90^{\circ} \mathrm{C}$, with a nikel concentration of $50 \%$ in electrolyte bath, current density $\mathrm{j}=3 \mathrm{~A} / \mathrm{dm}^{2}$ and $\mathrm{pH}=4.44$ 


\subsubsection{Effect of electrolyte concentration}

The morphology of the surfaces obtained from the five baths is also very different, as shown in Figure 4 (a-e) with a $\mathrm{Ni}$ electrolyte concentration of $10,25,50,75$ and $90 \%$, respectively. In the case of a reduced proportion of nickel in the electrolyte, cracks are evident on the surface and the deposition morphology tends to be non-uniform. (Figure 4a). Small dendrite like particles is seen throughout the surface in the case of deposits prepared with $25 \%$ Nickel in the electrolyte (Figure 4b). The increase of Nickel in the electrolyte makes the morphology of the deposits nonuniform, where the coatings are not homogeneous and have a large number of voids (Figure 4(c-e)). These results show that the content of $\mathrm{Ni}$ has a major effect on the morphology and grain size of the coatings. Several authors [5, 21, 22, 30, 31] have shown that electrolyte contents concentrations have an influence on the morphological shape of deposits. It was found that, the amount of Nickel in the coatings is increasing with the increase of the Nickel concentration in the electroplating baths.

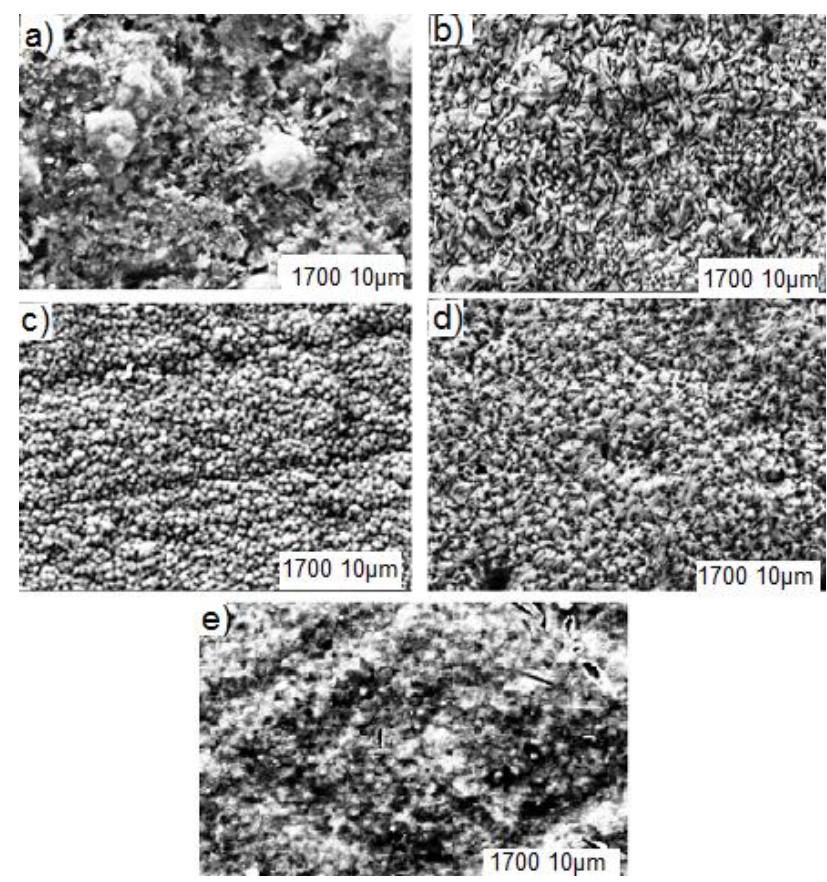

Figure 4. SEM micrographs of $\mathrm{Zn}-\mathrm{Ni}$ deposits prepared at different electrolyte concentration: a) $10 \mathrm{Ni}$, b) $25 \mathrm{Ni}$, c) $50 \mathrm{Ni}$, d) $75 \mathrm{Ni}$, e) $90 \mathrm{Ni}$, with bath temperature $30^{\circ} \mathrm{C}$, current density $\mathrm{j}=3 \mathrm{~A} \mathrm{dm}^{-2}$ and $\mathrm{pH}=4.44$

\subsection{Corrosion test (Weight loss)}

Figure 5 shows the variation of the corrosion rate $(\mathrm{W})$ as a function of the Nickel concentration in the electrolyte (Figure $5 \mathrm{a}$ ), the electrolyte temperature (Figure 5b) and the current density (Figure 5c), respectively. From the Figure 5a and 5b, the corrosion rate increased with the increase of Nickel proportion in the electrolyte as well as increases in bath temperature. The reason behind this behavior may be linked to that the higher temperature evalue leads to the higher growing rate of crystals, while the lower value corresponding to the formative of nuclei. Furthermore, according to atmospheric corrosion studies, the finer grain size of the $\mathrm{Zn}-\mathrm{Ni}$ coatings provides greater corrosion resistance. This can be attributed to the more compact $\mathrm{Zn}-\mathrm{Ni}$ coating structure, which is not readily invaded by $\mathrm{Cl}-$, ... etc. The finer grain size of the $\mathrm{Zn}-\mathrm{Ni}$ coatings $(1,754 \mathrm{~mm})$ could thus increase corrosion resistance $[18,25]$.

The Zn-Ni alloy, which has a lower corrosion potential, is less active than pure zinc. Zinc dissolves preferentially at the outset of the corrosion process, supplying the steel with galvanic protection. However, it contributes to $\mathrm{Ni}$ film enrichment (dezincification) and hence to the transfer of the corrosion capacity to more noble values, resulting in less protection of the steel. Furthermore, the maximum corrosion resistance is recorded in the range of $12-14 \%$ nickel content for $\mathrm{Zn}-\mathrm{Ni}$ coating [9] and this percentage has been obtained at $40^{\circ} \mathrm{C}$.

Figure $5 \mathrm{c}$ shows that, the increase of corrosion rate with the increase of the current density except in $3 \mathrm{~A}^{-\mathrm{dm}^{-2}}$ and the deposits with current density of $1.5 \mathrm{~A} . \mathrm{dm}^{-2}$ gives us higher corrosion resistance. The grain size and porosity of the coating increase with the increase in current density, and Ni deposition also increases as well.

The corrosion behavior of $\mathrm{Zn}-\mathrm{Ni}$ coatings is not only dependent on the chemical composition, but also on the phase composition. The highest corrosion resistance is the $\mathrm{Zn}-\mathrm{Ni}$ alloy composed of a $\gamma$-phase $\left(\mathrm{Ni}_{5} \mathrm{Zn}_{21}\right)$ [8]. Finally, the highest corrosion resistance of $\mathrm{Zn}-\mathrm{Ni}$ alloy deposits is obtained by $25 \%$ Nickel in the electrolyte and at $30^{\circ} \mathrm{C}$.
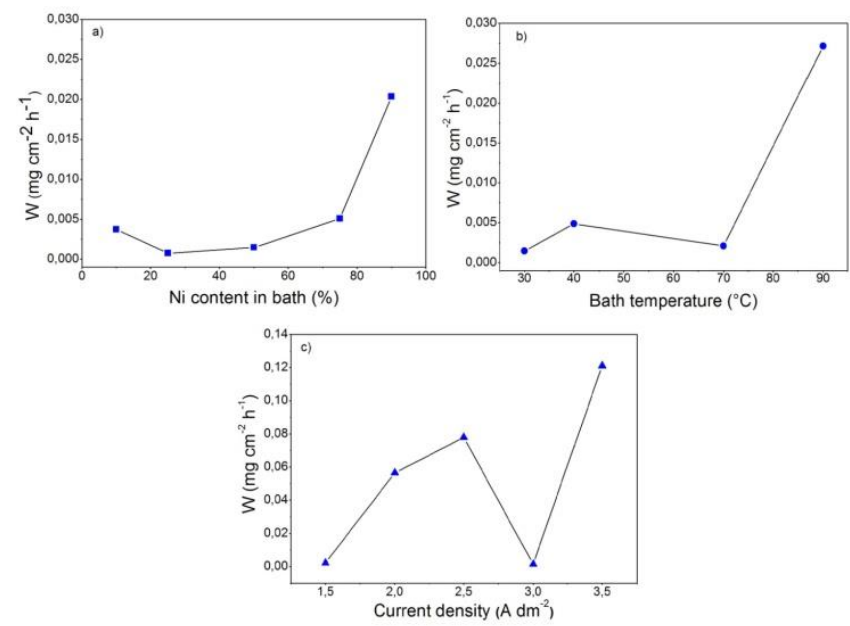

Figure 5. Corrosion rate (W) as a function of: a) Ni content in bath, b) bath temperature $\left({ }^{\circ} \mathrm{C}\right)$ and c) current density (A $\left.\mathrm{dm}^{-2}\right)$

\subsection{Microhardness evolution}

Table 3 summarizes the microhardness values of the different $\mathrm{Zn}-\mathrm{Ni}$ alloy deposits. It is clear that the microhardness of the coatings is strongly related to the proportion of Nickel deposited with zinc. It is noted that deposits of $\mathrm{Zn}-\mathrm{Ni}$ alloys with a proportion of 25 and $75 \%$ of $\mathrm{Ni}$ in the electrolytes have the maximum values of the microhardness.

Generally, Due to the intrinsic property of nickel, the microhardness of $\mathrm{Zn}-\mathrm{Ni}$ alloy with a greater nickel content is high [14]. For zinc coatings, the estimated microhardness value should be between 100 and $140 \mathrm{Hv}$ [32]. There was an improvement in hardness with a $\mathrm{Zn}-\mathrm{Ni}$ alloy with a higher $\mathrm{Ni}$ content, due to the higher Ni hardness than that of $\mathrm{Zn}-\mathrm{Ni}$. This suggests that the primary element in the hardening process of $\mathrm{Zn}-\mathrm{Ni}$ alloy coatings is the Ni content [33].

It is assumed, on the basis of these interpretations, that the 
change in the proportion of nickel is primarily due to the ratio of zinc to nickel concentrations $\left(\mathrm{Zn}^{2+} / \mathrm{Ni}^{2+}\right)$. If this ratio is greater, the coatings give us very high concentrations of nickel [19], so the hardness levels in the deposit would decline with low nickel values [19].

Table 3. Microhardness values of the deposits

\begin{tabular}{cc}
\hline Sample & Microhardness (Hv) \\
\hline Steel & 144.5 \\
$10 \% \mathrm{Ni}$ & 280.22 \\
$25 \% \mathrm{Ni}$ & 521 \\
$50 \% \mathrm{Ni}$ & 327.75 \\
$75 \% \mathrm{Ni}$ & 569.33 \\
$90 \% \mathrm{Ni}$ & 378 \\
\hline
\end{tabular}

\section{CONCLUSIONS}

In the present investigation, the effect of some factors on the surface of the Zinc - Nickel alloy deposited on an industrial low carbon steel against corrosion by using a chloride electrolyte, were investigated using X-ray diffraction, scanning electronic microscopy and Vickers microhardness.

The X-ray diffraction analysis shows the presence of two phases: $\delta$-phase $\left(\mathrm{Ni}_{3} \mathrm{Zn}_{22}\right)$ and $\gamma$-phase $\left(\mathrm{Ni}_{5} \mathrm{Zn}_{21}\right)$, with the increase of the peaks intensities of this later with the increasing of the Ni proportion in the electrolyte.

A full dissolution of $\mathrm{Ni}_{3} \mathrm{Zn}_{22}$ phase was observed in the electrolyte with $90 \%$-Ni.

The scanning electron microscope (SEM) observations show a pyramidal morphology with conditions of $\mathrm{T}=40^{\circ} \mathrm{C}$, $\mathrm{j}=3 \mathrm{~A} \mathrm{dm}^{-2}$ and $50 \%$-Ni in the electrolyte.

The increase of the Ni content in the electrolyte leads to an irregular morphology.

Generally, the corrosion rate increases with the increase of the Ni proportion in the electrolyte, temperature bath and the current density.

The best corrosion resistance was obtained with factors of $25 \%-\mathrm{Ni}$ in the electrolyte and at $30^{\circ} \mathrm{C}$.

The microhardness measurements show that the $\mathrm{Zn}-\mathrm{Ni}$ alloy deposits with 25 and $75 \%$ Nickel have higher values compared with the others concentrations.

\section{ACKNOWLEDGMENT}

We would like to thank all members of material science department, University of Biskra for their help and facilities.

\section{REFERENCES}

[1] Pei, Z., Zhang, D., Zhi, Y., Yang, T., Jin, L., Fu, D., Li, $\mathrm{X}$. (2020). Towards understanding and prediction of atmospheric corrosion of an $\mathrm{Fe} / \mathrm{Cu}$ corrosion sensor via machine learning. Corrosion Science, 170: 108697. https://doi.org/10.1016/j.corsci.2020.108697

[2] Finkenstadt, V.L., Côté, G.L., Willett, J.L. (2011). Corrosion protection of low-carbon steel using exopolysaccharide coatings from Leuconostoc mesenteroides. Biotechnology Letters, 33(6): 1093-1100. https://doi.org/10.1007/s10529-011-0539-2

[3] Gerengi, H., Sahin, H.I. (2012). Schinopsis lorentzii extract as a green corrosion inhibitor for low carbon steel in $1 \mathrm{M} \mathrm{HCl}$ solution. Industrial \& Engineering Chemistry Research, $\quad 51(2)$ : https://doi.org/10.1021/ie201776q

780-787.

[4] Saxena, A., Sharma, V., Thakur, K.K., Bhardwaj, N. (2020). Electrochemical Studies and the Surface Examination of Low Carbon Steel by Applying the Extract of Citrus sinensis. Journal of Bio-and TriboCorrosion, 6(2): 1-11. https://doi.org/10.1007/s40735020-00338-x

[5] Abou-Krisha, M.M. (2005). Electrochemical studies of zinc-nickel codeposition in sulphate bath. Applied Surface Science, 252(4): 1035-1048. https://doi.org/10.1016/j.apsusc.2005.01.161

[6] El Hajjami, A., Gigandet, M.P., De Petris-Wery, M., Catonne, J.C., Duprat, J.J., Thiery, L. (2007). Characterization of thin $\mathrm{Zn}-\mathrm{Ni}$ alloy coatings electrodeposited on low carbon steel. Applied Surface Science, 254(2): 480-489. https://doi.org/10.1016/j.apsusc.2007.06.016

[7] Fratesi, R., Roventi, G. (1996). Corrosion resistance of $\mathrm{Zn}-\mathrm{Ni}$ alloy coatings in industrial production. Surface and Coatings Technology, 82(1-2): 158-164. https://doi.org/10.1016/0257-8972(95)02668-1

[8] Byk, T.V., Gaevskaya, T.V., Tsybulskaya, L.S. (2008). Effect of electrodeposition conditions on the composition, microstructure, and corrosion resistance of $\mathrm{Zn}-\mathrm{Ni}$ alloy coatings. Surface and Coatings Technology, 202(24): 5817-5823. https://doi.org/10.1016/j.surfcoat.2008.05.058

[9] Bajat, J.B., Petrović, A.B., Maksimović, M.D. (2005). Electrochemical deposition and characterization of zincnickel alloys deposited by direct and reverse current. Journal of the Serbian Chemical Society, 70(12): 14271439. https://doi.org/10.2298/JSC0512427B

[10] Velichenko, A.B., Portillo, J., Sarret, M., Muller, C. (1999). Surface analysis of films formed on a zinc anode in a $\mathrm{Zn}-\mathrm{Ni}$ electroplating bath. Applied Surface Science, 148(1-2): 17-23. https://doi.org/10.1016/S01694332(99)00140-3

[11] Felloni, L., Fratesi, R., Quadrini, E., Roventi, G. (1987). Electrodeposition of zinc-nickel alloys from chloride solution. Journal of Applied Electrochemistry, 17(3): 574-582. https://doi.org/10.1007/BF01084132

[12] Albalat, R., Gómez, E., Müller, C., Sarret, M., Vallés, E., Pregonas, J. (1990). Electrodeposition of zinc-nickel alloy coatings: influence of a phenolic derivative. Journal of Applied Electrochemistry, 20(4): 635-639. https://doi.org/10.1007/BF01008875

[13] Albalat, R., Gomez, E., Müller, C., Pregonas, J., Sarret, M., Valles, E. (1991). Zinc-nickel coatings: Relationship between additives and deposit properties. Journal of Applied Electrochemistry, 21(1): 44-49. https://doi.org/10.1007/BF01103828

[14] Deepa, K., Venkatesha, T.V. (2017). Synthesis and generation of $\mathrm{CuO}$ and $\mathrm{Mn}$ doped $\mathrm{CuO}$ composites and its corrosion behaviour. Materials Today: Proceedings, 4(11): https://doi.org/10.1016/j.matpr.2017.09.129

[15] Hegde, A.C., Venkatakrishna, K., Eliaz, N. (2010). Electrodeposition of $\mathrm{Zn}-\mathrm{Ni}, \mathrm{Zn}-\mathrm{Fe}$ and $\mathrm{Zn}-\mathrm{Ni}-\mathrm{Fe}$ alloys. Surface and Coatings Technology, 205(7): 2031-2041. https://doi.org/10.1016/j.surfcoat.2010.08.102

[16] Lotfi, N., Aliofkhazraei, M., Rahmani, H., Darband, G. B. (2018). Zinc-nickel alloy electrodeposition: 
Characterization, properties, multilayers and composites.

Protection of Metalsand Physicalchemistryof Surfaces, 54(6):

$1102-1140$ https://doi.org/10.1134/s2070205118060187

[17] Obot, I.B., Obi-Egbedi, N.O., Umoren, S.A. (2009). Ginseng root: a new efficient and effective eco-friendly corrosion inhibitor for aluminium alloy of type AA 1060 in hydrochloric acid solution. Electrochem, 4(9): 1277 1288.

[18] Tsybulskaya, L.S., Gaevskaya, T.V., Purovskaya, O.G., Byk, T.V. (2008). Electrochemical deposition of zincnickel alloy coatings in a polyligand alkaline bath. Surface and Coatings Technology, 203(3-4): 234-239. https://doi.org/10.1016/j.surfcoat.2008.08.067

[19] Panikkar, S.K., Char, T.R. (1959). Electroplating of Nickel from the Pyrophosphate Bath. Journal of the Electrochemical Society, 106(6): 494 http://dx.doi.org/10.1149/1.2427395

[20] Abou-Krisha, M.M. (2005). Electrochemical studies of zinc-nickel codeposition in sulphate bath. Applied Surface $\quad$ Science, 252(4): 1035-1048. http://dx.doi.org/10.1016/0257-8972(96)02857-5

[21] Irfan, H., Racik, K.M., Anand, S. (2018). X-ray peak profile analysis of $\mathrm{CoAl}_{2} \mathrm{O}_{4}$ nanoparticles by Williamson-Hall and size-strain plot methods. Modern Electronic Materials, 4: 31 http://dx.doi.org/10.3897/j.moem.4.1.33272

[22] Benballa, M., Nils, L., Sarret, M., Müller, C. (2000). Zinc-nickel codeposition in ammonium baths. Surface and Coatings Technology, 123(1): 55-61. https://doi.org/10.1016/S0257-8972(99)00397-7

[23] Alfantazi, A.M., Page, J., Erb, U. (1996). Pulse plating of $\mathrm{Zn}-\mathrm{Ni}$ alloy coatings. Journal of Applied Electrochemistry, 26(12): 1225-1234. https://doi.org/10.1007/BF00249924

[24] Qiao, X., Li, H., Zhao, W., Li, D. (2013). Effects of deposition temperature on electrodeposition of zincnickel alloy coatings. Electrochimica Acta, 89: 771-777. https://doi.org/10.1016/j.electacta.2012.11.006

[25] Abou-Krisha, M.M. (2005). Electrochemical studies of zinc-nickel codeposition in sulphate bath. Applied
Surface $\quad$ Science, $252(4)$ : $\quad$ 1035-1048. https://doi.org/10.1016/0257-8972(96)02857-5

[26] Rahman, M.J., Sen, S.R., Moniruzzaman, M., Shorowordi, K.M. (2009). Morphology and properties of electrodeposited $\mathrm{Zn}-\mathrm{Ni}$ alloy coatings on mild steel. Journal of Mechanical Engineering, 40(1): 9-14. https://doi.org/10.3329/jme.v40i1.3468

[27] Lin, C.C., Huang, C.M. (2006). Zinc-nickel alloy coatings electrodeposited by pulse current and their corrosion behavior. JCT Research, 3(2): 99-104. https://doi.org/10.1007/s11998-006-0011-8

[28] Ashassi-Sorkhabi, H., Hagrah, A., Parvini-Ahmadi, N., Manzoori, J. (2001). Zinc-nickel alloy coatings electrodeposited from a chloride bath using direct and pulse current. Surface and Coatings Technology, 140(3): 278-283. https://doi.org/10.1016/S0257-8972(01)010325

[29] Abd El Rehim, S.S., Fouad, E.E., Abd El Wahab, S.M., Hassan, H.H. (1996). Electroplating of zinc-nickel binary alloys from acetate baths. Electrochimica Acta, 41(9): 1413-1418. https://doi.org/10.1016/00134686(95)00327-4

[30] Beltowska-Lehman, E., Ozga, P., Swiatek, Z., Lupi, C. (2002). Influence of structural factor on corrosion rate of functional $\mathrm{Zn}-\mathrm{Ni}$ coatings. Crystal Engineering, 5(3-4): 335-345. https://doi.org/10.1016/S1463-0184(02)00045$\mathrm{X}$

[31] Barcelo, G., Garcia, J., Sarret, M., Müller, C., Pregonas, J. (1994). Properties of $\mathrm{Zn}-\mathrm{Ni}$ alloy deposits from ammonium baths. Journal of Applied Electrochemistry, 24(12): 1249-1255. https://doi.org/10.1007/BF00249889

[32] Dutra, C.A., Silva, J.W., Nakazato, R.Z. (2013). Corrosion Resistance of $\mathrm{Zn}$ and $\mathrm{Zn}-\mathrm{Ni}$ electrodeposits: Morphological characterization and phases identification. Materials Sciences and Applications, 4(10): 644-648. http://dx.doi.org/10.4236/msa.2013.410079

[33] Feng, Z., Li, Q., Zhang, J., Yang, P., Song, H., An, M. (2015). Electrodeposition of nanocrystalline $\mathrm{Zn}-\mathrm{Ni}$ coatings with single gamma phase from an alkaline bath. Surface and Coatings Technology, 270: 47-56. https://doi.org/10.1016/j.surfcoat.2015.03.020 